\title{
佐波川におけるオオカナダモ被度の定量化と 繁茂要因の検討
}

\author{
QUANTIFICATION OF COVER DEGREE OF ALIEN AQUATIC WEEDS AND \\ ENVIRONMENTAL CONDITIONS AFFECTING THE GROWTH OF Egeria densa \\ IN SABA RIVER, JAPAN
}

\author{
乾 隆帝 $1 \cdot$ 赤松良久 $2 \cdot$ 掛波優作 ${ }^{3}$ \\ Ryutei INUI, Yoshihisa AKAMATSU, Yusaku KAKENAMI \\ 1正会員 博 (農) 山口大学大学院 助教 (特命) 理工学研究科社会建設工学専攻 \\ （干755-8611 山口県宇部市常盤台2-16-1） \\ 2正会員 博 (工) 山口大学大学院 准教授 理工学研究科社会建設工学専攻 \\ （干755-8611 山口県宇部市常盤台2-16-1） \\ 3非会員 山口大学工学部 社会建設工学科（干755-8611 山口県宇部市常盤台2-16-1）
}

\begin{abstract}
Monitoring the thickness of the alien aquatic weed Egeria densa overgrowth and identifying the environmental conditions that affect its growth are important factors for its management in rivers. In this study, unmanned aerial vehicle (UAV) was used to establish a method to quantify the cover degree of $E$. densa. In addition, environmental conditions that affect the cover degree of $E$. densa were explored by using fluid models, geographic information system (GIS), and generalized linear models (GLM). The results of this study showed that the cover degree of $E$. densa can be easily quantified by using images taken by UAV and GIS. Furthermore, the results of GLM showed that the distance from weir located downstream is the most effective parameter for the cover degree of $E$. densa.
\end{abstract}

Key Words: UAV, drone, alien species, aquatic weed, river, GIS, GLM, fluid model, Eco hydraulics

\section{1. はじめに}

オオカナダモは，南米原産の外来沈水植物である1). 切れ藻による無性増殖で分布域を拡大することができる ため，日本だけでなく，世界各地に移入定着しており1), 2), 日本生態学会が選定した「日本の侵略的外来種ワー スト100」にも含まれている21.

陸水域における外来沈水植物の侵入は，生物多様性の 低下や水質の悪化をもたらす可能性が高いため, 適切な 管理をおこなう必要がある3). 本種は，従来は，湖沼や 水路を中心に繁茂しており4),5), 船の走行の妨げや, 岸 に打ち寄せられ腐敗することにより悪臭を発することが 問題視されていたが5)，近年は，河川の本流でも繁茂し ている事例が数多く報告されており，これらの河川では，
実際に景観悪化や漁業被害が生じている6).

このような背景から，才オカナダモの侵入や繁茂をモ ニタリングし，さらには，繁茂に影響を与える要因を解 明し，繁茂抑制をおこなうことは必須である。しかしな がら，日本の河川において，才オカナダモの繁茂状況を 定量化し，繁茂条件を解明した研究例はほとんどない. その理由として, 従来の調査手法で沈水植物を定量モ二 タリングする場合には, 時間, 労力, 金銭ともにコスト が大きいため7であると予想される.

そこで本研究では，近年植生調査に用いられることが 多くなっているUAV（Unmanned aerial vehicle : 無人航空 機）を用いて ${ }^{8)}$, 河川におけるオオカナダモの被度を定 量モニタリングする手法を確立し，さらに，得られた データを用いて，オオカナダモの被度を左右する環境条 件を明らかにすることを試みた。 


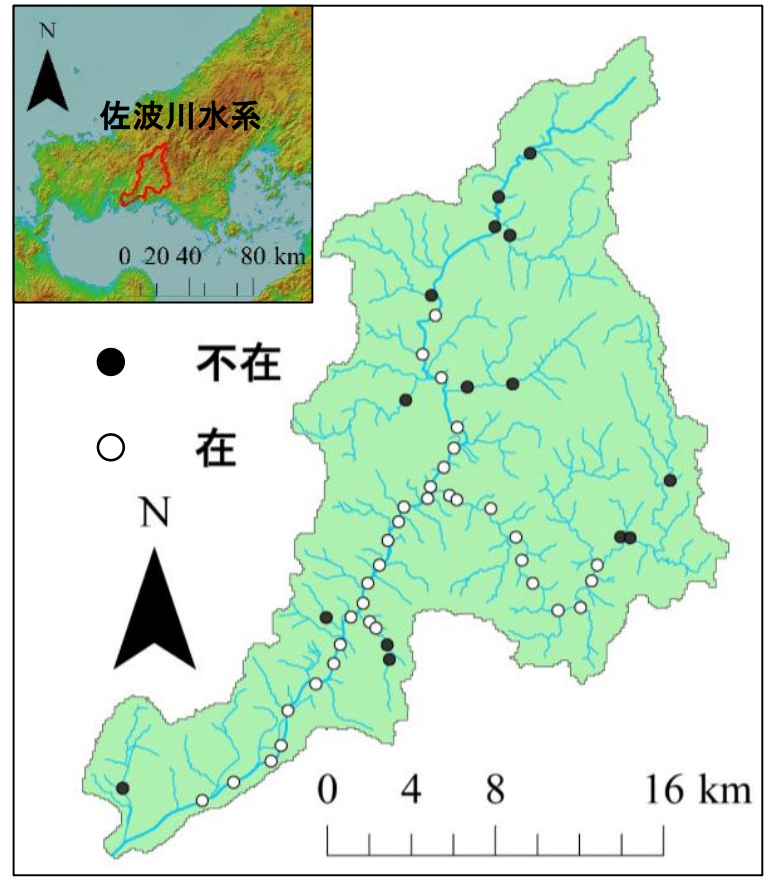

図-1 佐波川水系におけるオオカナダモの分布状況

\section{2. 方法}

（1） 佐波川水系におけるオオカナダモの分布調査

本研究の対象地には, 予備調査によって, 河川本流に オオカナダモが繁茂していることが明らかとなっていた 佐波川水系を選択した。佐波川は山口県のほぼ中央に位 置し，周防灘に注ぐ幹川流路延長 $56 \mathrm{~km}$ ，流域面積 $460 \mathrm{~km}^{2}$ の一級水系である. オ才カナダモの水系内におけ る分布状況の把握と，空中撮影をおこなうエリアの選定 を目的として，2015年8月5日から9日にかけて，佐波川 水系の本川および支川の50地点（図-1）において，水上 からの目視観察による分布調査をおこなった.すべての 地点において，ハンディGPSおよびデジタルカメラを用 いて，位置座標の記録をおこなった。

\section{（2）分布を左右する地形特性の把握}

赤松ら9)に従い，ArcGIS10.2（ESRI）を用い，50m メッシュの数值標高モデル（DEM）を用いて小流域を 作成し, 各小流域における平均標高, 平均傾斜角, 平均 SPI（Stream Power Index）, 平均TWI（Topographical Wetness Index）を算出した. SPIは土砂の侵食の起こり やすさを示し，TWIは土砂の溜まりやすさを示す変数で あり，ともに集水域面積と傾斜角から算出される. 野外 調査によって得られたオオカナダモの分布情報を小流域 単位で再整理し，オオカナダモが分布していた小流域と 分布していなかった小流域間の地形特性を, MannWhitneyのU検定を用いて比較検定した。

\section{（3） オオカナダモの繁茂状況の把握}

前述した佐波川水系内の分布調査によって明らかに
なった繁茂エリアにおいて，UAVを用いた空中撮影を おこなうことにより，才オカナダモの被度を算出した. 手順は以下のとおりである。まず，2015年9月13日から 15日にかけて，Phantom3（DJI）を用いて堤防一堤防間 の動画を撮影した後, Image Composite Editor (Microsoft Corporation）を用いて歪みを最小限に修正したスナップ ショット画像を作成した.さらに，その画像をArcGIS 10.2のジオリファレンス機能を用いて位置座標を定義づ け，オオカナダモ群落をトレースするポリゴンおよび低 水路のポリゴンを作成した。 なお，群落をトレースする 際の最小面積は $4 \mathrm{~m}^{2}$ に設定した。最後に，作成されたポ

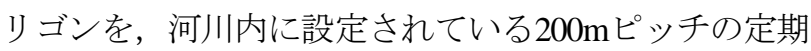
横断側線で切断することにより，河川縦断方向に $200 \mathrm{~m}$ 範囲内のオオカナダモ群落および低水路の面積を算出し, オオカナダモ群落の面積を低水路面積で除することによ り，低水路におけるオオカナダモの被度を算出した（図 -2）。なお，撮影区間内では，実際の目視調査により， $4 \mathrm{~m}^{2}$ 以上の在来沈水植物の純群落がないことは確認済み である。

\section{（4）オオカナダモの被度を左右する環境の抽出}

オオカナダモの被度を左右する環境条件を明らかにす るため，繁茂エリアにおける低水路の平均河床高，夏季 平水時の平均的な流れ場の特性（流速，水深）の算出, 堰からの距離の算出, および水質の観測をおこなった.

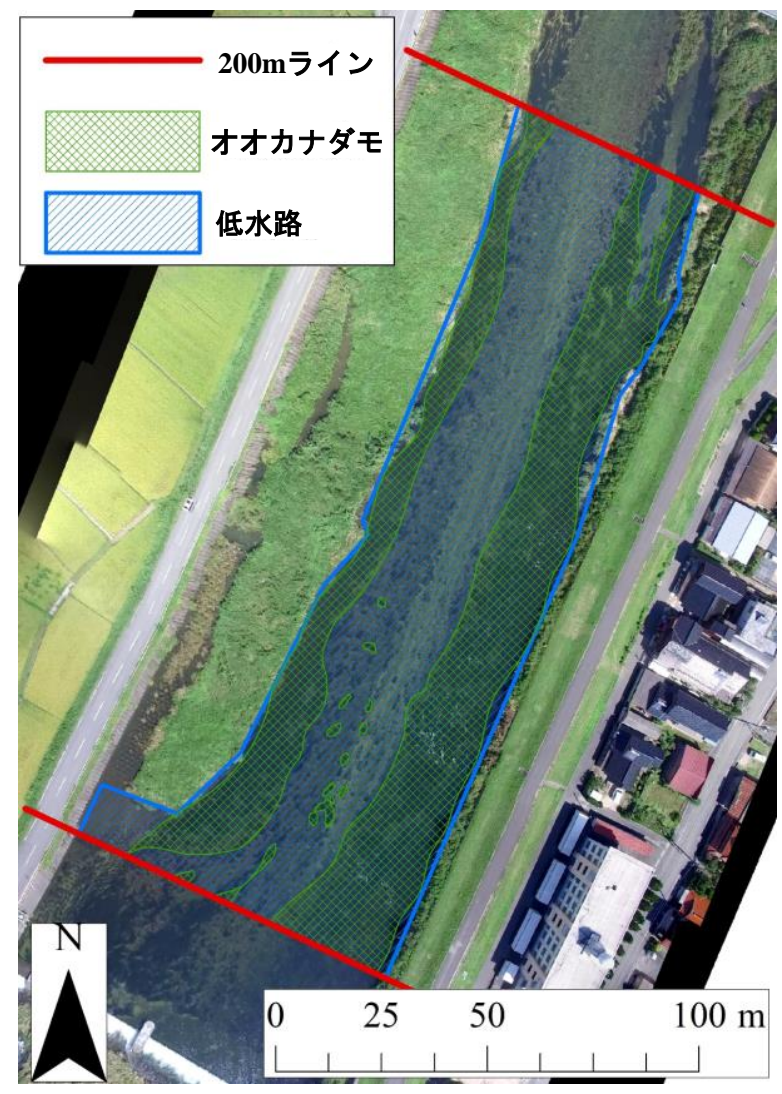

図-2 低水路におけるオオカナダモの被度を算出す る方法のイメージ 


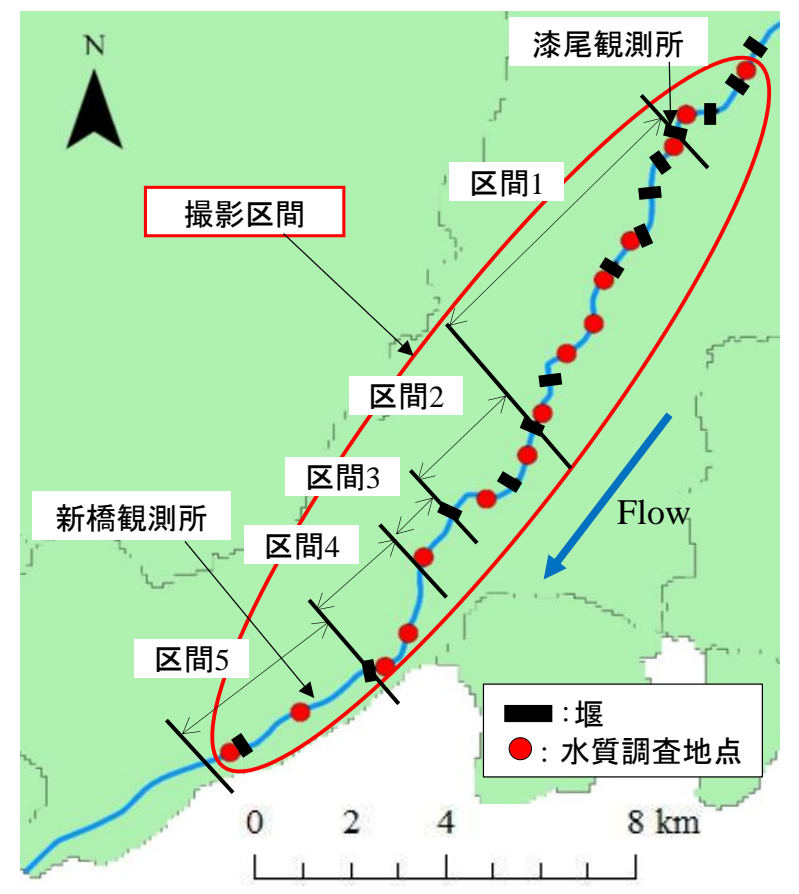

図-3＼cjkstart水質の調査地点と計算区間

河床高および流れ場の特性は, 河川の流れ場の計算ソ フトウェアであるiRIC（International River Interface Cooperative）ソフトウェアを用いて算出した. 計算には Nays2D Floodソルバーを用いた．計算に用いた断面デー 夕は，2009年8月に行われた200mピッチの定期横断測量 結果を元に作成したメッシュデータを用いた. 境界条件 としては，上流端流量に8月の漆尾観測所の平水流量 $\left(18.09 \mathrm{~m}^{3} / \mathrm{s}\right)$ を与え，下流端は等流水深とした。 また, 取水や支流による影響を考慮するため，5分割して計算 を行った（図-3）。支流などの横流入に関しては，上流 端の漆尾観測所の流量 (8月の平水流量 $\left.18.09 \mathrm{~m}^{3} / \mathrm{s}\right)$ と, 全区間の取水流量（8月の平水取水量 $6.25 \mathrm{~m}^{3} / \mathrm{s}$ ) を足した 新橋観測所の平水流量 $\left(24.34 \mathrm{~m}^{3} / \mathrm{s}\right)$ の流量差から, 計算 区間内の全横流入量を算出し，各支流の持つ集水面積割 合で割り振ることにより算出した．さらに，算出された 河床高, 流速, および水深データは, 河川縦断方向に $200 \mathrm{~m}$ 範囲で作成した低水路ユニット（以下低水路ユ ニット）で平均值を集計した. 集水域面積の算出および 計算結果の集計にはArcGIS 10.2を用いた．堰からの距離 については, 低水路ユニットの上流端から上流方向の最 寄りの堰までの距離（以下，上流方向の堰までの距離) および下流端から下流方向の最寄りの堰までの距離（以 下，下流方向の堰までの距離）を算出した．なお，低水 路ユニット内に堰が存在した場合は，下流方向の堰まで の距離および上流方向の堰までの距離をともに0として 計上した．水質は，2015年9月14日から15日にかけて撮 影区間をおおむ祆カバーするような15地点で採水をおこ ない（図-3），BLTEC社の全自動水質計測器SWAATを 用い，T-NおよびT-Pを算出した。 さらに，これらの值 を，ArcGIS 10.2を用いて内挿補完することにより， 200m範囲の低水路ユニットにおける平均值を算出した.

\section{（5）統計解析手法}

一般化線形モデルを用いて，オオカナダモの被度に影 響を及ぼす要因を明らかにすることを試みた。目的変数 は，低水路ユニットにおけるオオカナダモの被度を用い， 説明変数には, 低水路ユニットごとの流速, 河床高, 水 深，上流方向の堰までの距離，下流方向の堰までの距離, T-NおよびT-Pを用いた。 なお，オオカナダモの被度が， 各変数に対し，明らかに中間的な值でピークを迎える場 合においては，それら変数の2乗項も加えた，なお，解 析には統計ソフトR3.2.1（R Development Core Team）を 用いた。

\section{3. 結果と考察}

\section{（1） オオカナダモの水系内分布を左右する地形特性}

目視観察調查の結果, 全50地点中 35 点においてオオカ ナダモの分布を確認することができた．分布データを小 流域単位で整理し，オオカナダモが分布していた小流域 と分布していなかった小流域間で平均標高，平均傾斜角， 平均SPI, 平均TWIをMann-WhitneyのU検定を用いて比 較検定したところ，すべての変数間で有意差（p<0.01） がみられた（図-4）。オオカナダモが分布していた小流 域のほうが標高, 傾斜角, SPI ともに小さく, TWIは大 きいことが示された. これらの結果から，佐波川水系に おいてオオカナダモは，在／不在レベルは，比較的下流 的な環境をもつ小流域に分布する傾向を示したと言える.
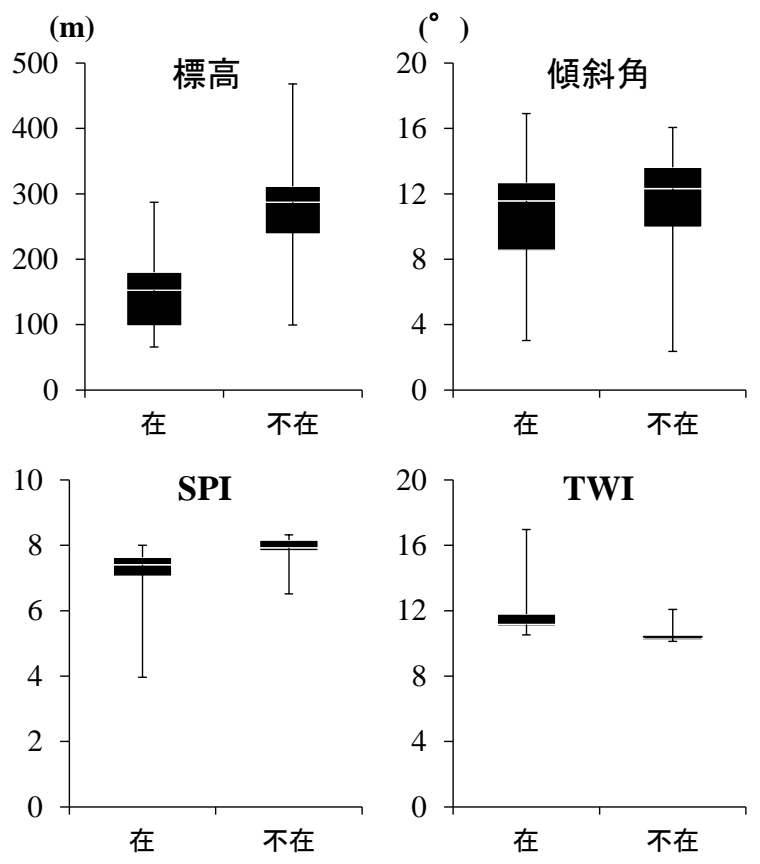

図-4 オオカナダモが分布していた小流域と分布し ていなかった小流域間の地形特性の比較 

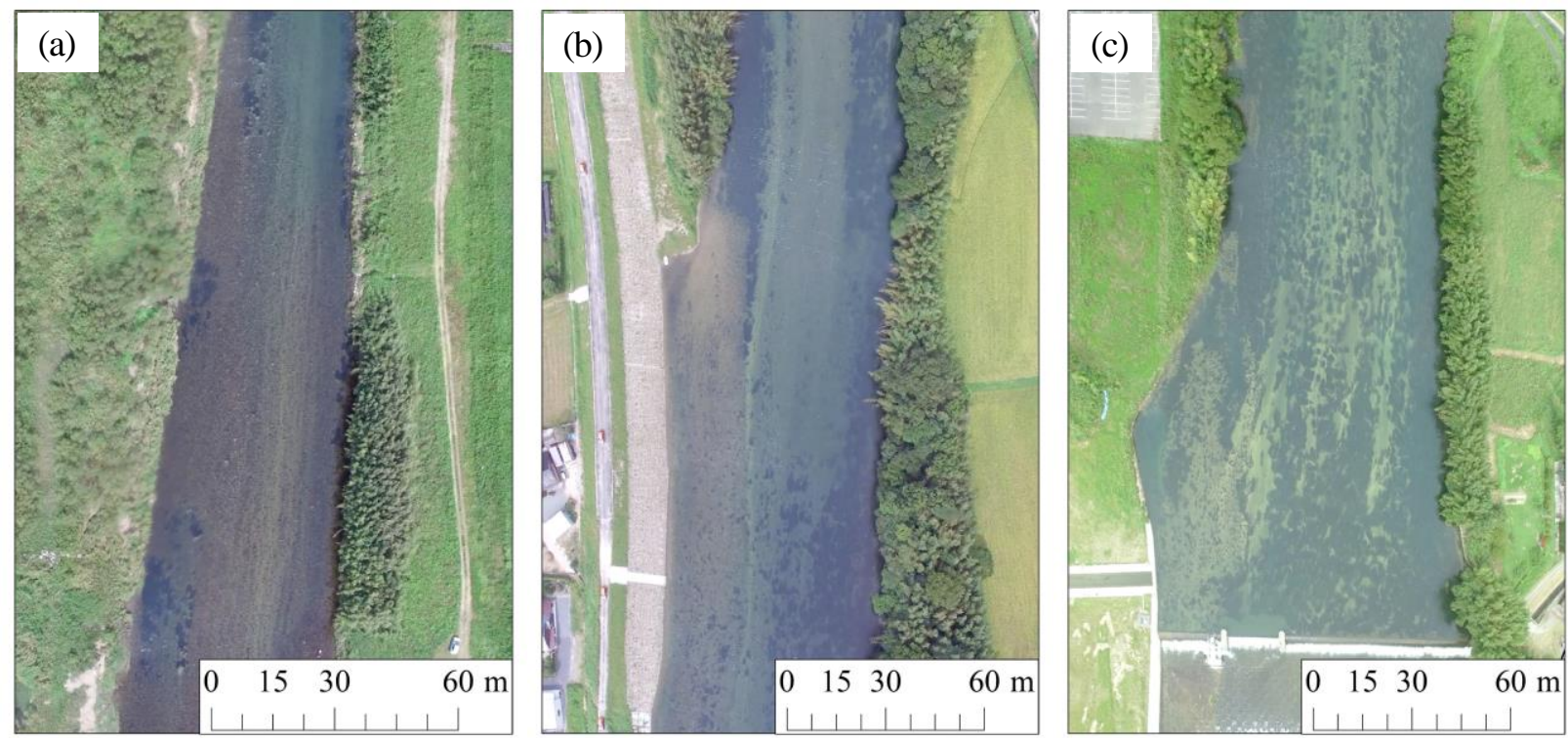

図-5 UAVによって撮影されたオオカナダモの空中写真. 各画像を含む低水路ユニットの被度は(a) $3.5 \%$, (b) $18.2 \% ，$ (c) $50.5 \%$ ． 撮影場所は河口から (a) $10.7 \mathrm{~km} ，$ (b) $13.7 \mathrm{~km} ，$ (c) $14.7 \mathrm{~km}$ 付近

\section{（2）オオカナダモの被度を左右する環境特性}

UAVを用いたオオカナダモの被度の調査は，水系内 分布調査で連続して分布が確認された本川の中下流域

（図-3）でおこなった，撮影の結果，図-5に示すような 明瞭な空中写真を得ることができ，場所によって，被度 が大きく異なっていることが見てとれた。低水路ユニッ トで集計した被度を図-6に示している。被度は最大で 81.2\%であった。被度と環境特性についての関係性を図7に示している．流速とT-Pについては中間にピークを持 つ関係性，水深，上流方向の堰までの距離，および下流 方向の堰までの距離については負の関係性，河床高と TNについては正の関係性を持つ傾向が見受けられたため, 一般化線形モデルを構築する際に，流速とT-Pについて は，それぞれの2乗項を説明変数に加えた.

一般化線形モデルの結果を表-1に示している. AICの 低い上位10モデルに選択された変数の回数と関係性をみ てみると，下流方向の堰までの距離は，10モデル全てで 選択されており，負の関係性を持っていることが明らか になった．河床高は上位10モデル中9モデルで選択され ており，正の関係性を持っていることが明らかになった。 流速は上位10モデル中7モデルで選択されており正の, 流速の2乗項は8モデルで選択されており負の関係性を 持っていることが明らかになった．また，水深，上流方 向の堰までの距離，T-N，T-PおよびT-Pの2乗項はいず れも3回以下の選択であった。

AICの低い上位モデルにおける変数の選択回数を関係 性の強さの基準とすると，才オカナダモの被度には，下 流方向の堰までの距離が最も強く関係しており, 他にも 河床の高さおよび流速が強い関係性を持っている. 一方, 水深や，上流方向の堰までの距離，水質との関係性が弱 いことが示された. オオカナダモの被度と関係性が強
かった3変数の応答曲線は図-8に示している。これらの 結果をまとめると，佐波水系においては，才オカナダモ は，堰の上方でかつ堰に近く，流速が中程度（約 $0.57 \mathrm{~m} / \mathrm{s}$ ) で，撮影区間の中では上流側で繁茂しや寸い 傾向を示しているといえる，堰の上流側には，平水時で は湛水区間が生じること, 出水時でも流速が遅くなるこ とや，河床の移動が抑制されることが要因であると考え られる．また，流速が中程度であるという結果は，佐波 川水系においては，オオカナダモ自体が，完全な止水域

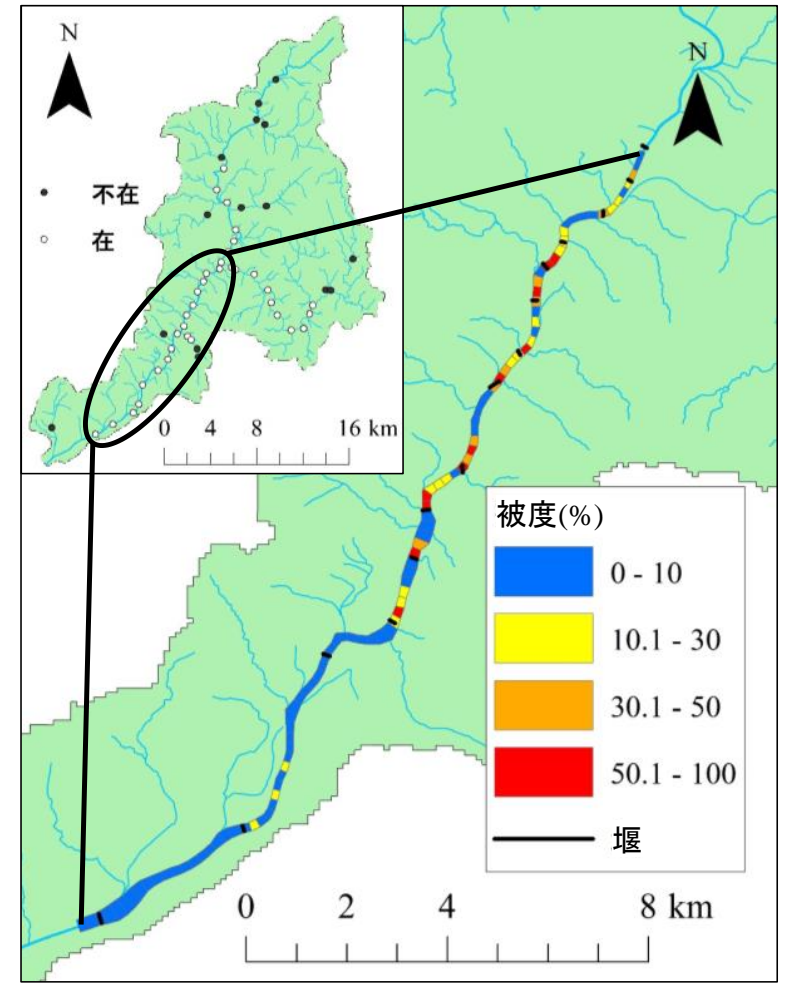

図-6＼cjkstart撮影エリアにおける低水路ユニット毎の被度 
よりも，やや流れている区間のほうを好む可能性を示し ている．また，調査区間では上流側で被度が高くなった 理由としては，上流側には堰が連続して存在することに より，出水時の影響を受けづらい個体群が存在すること， そして供給源が常に近傍にあることが可能性として考え られる（図-3）。この結果は, 前述した, 在/不在レベ ルの分布傾向と一見相反するように見えるが，生息でき るか娝かと，広範囲に繁茂するか娝かを左右する環境条 件は異なっている可能性が高いことを示唆している。ま た，水質との関係性がみられなかったことから，佐波川 においては，局所的な富栄養化が繁茂要因となっている 可能性は少ないと考えられる.

本研究ではオオカナダモの被度は, 流速や水深といっ た直接的に生息に影響を与えると考えられる環境条件よ
りも，堰との位置関係といった間接的に生育に影響を与 える環境条件に強く左右される結果となった。これはお そらく，本研究では出水時の流れ場の特性を加味してい ないことや，堰の影響による流れ場や土砂動態の変化を 加味していないためだと予想される. 本研究で構築した 手法により，河川広域におけるオオカナダモの繁茂状況 が簡易に定量化できるようになった．今後は，季節変動 や，出水前後のモニタリングをおこなうとともに，出水 時の影響や土砂動態を加味した水理シミュレーションを 行うことにより，本種の繁茂メカニズムや，繁茂抑制に 寄与する知見が得られるだろう。

\section{4. 結論}
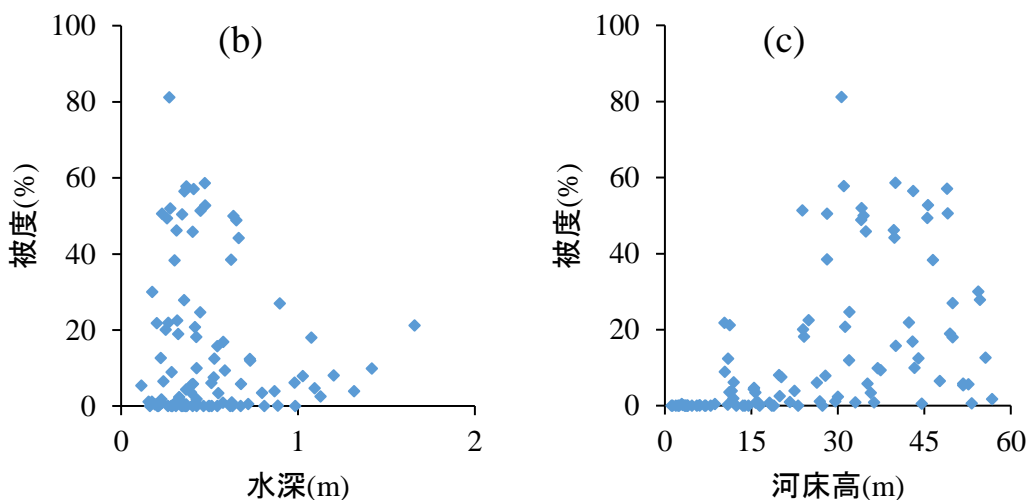
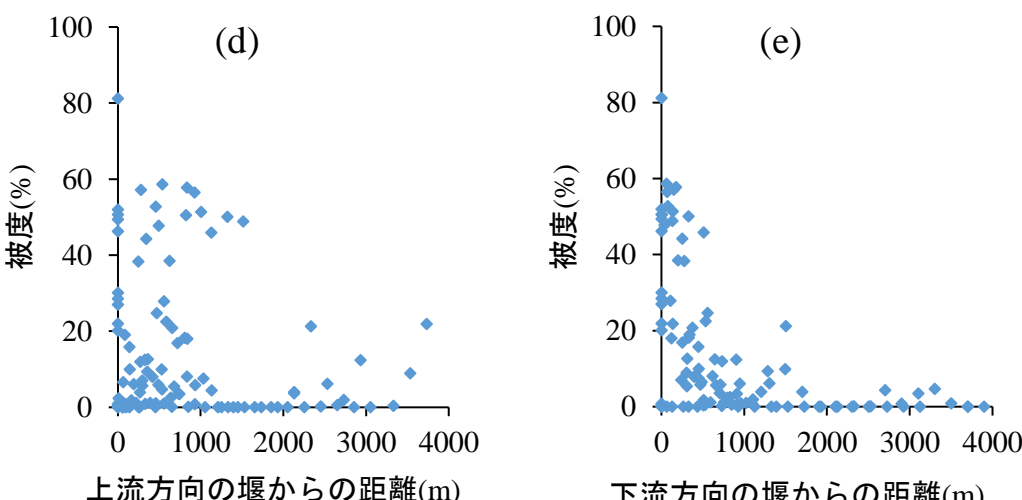

下流方向の堰からの距離 $(\mathrm{m})$
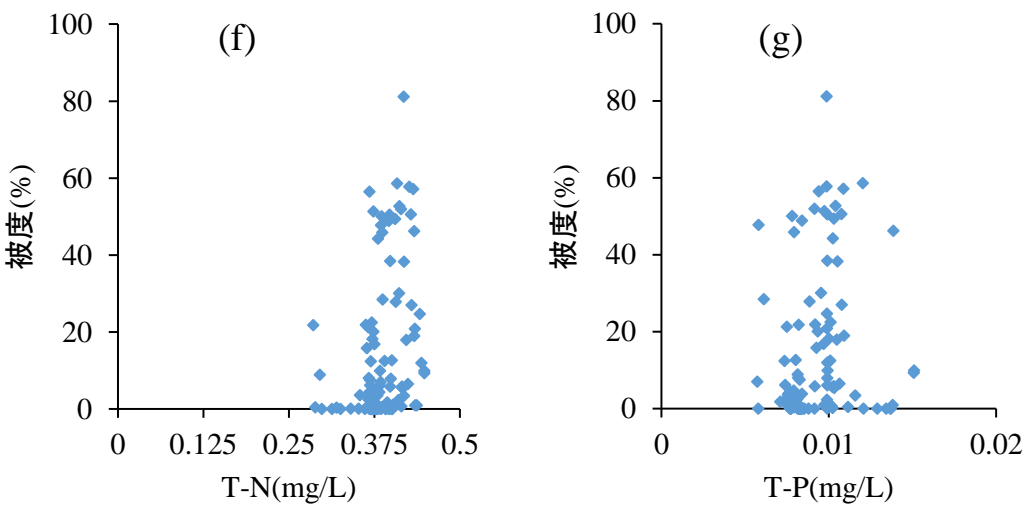

図-7 オオカナダモの被度と環境特性についての関係性. (a) 流速, (b) 水深, (c) 河床高, (d) 上流方向の堰からの距離, （e）下流方向の堰からの距離, (f) T-N, (g) T-P 
表-1 GLMの結果. AICを基準に選択した上位5モデルの切片および变数の係数および標準偏差と, 上位10モデルにおける各変数の選択回数を示している

\begin{tabular}{|c|c|c|c|c|c|c|c|c|c|c|}
\hline \multirow{2}{*}{\multicolumn{2}{|c|}{ AIC }} & \multicolumn{9}{|c|}{ 係数 (標準偏差) } \\
\hline & & 切片 & 流速 & 流速2乗 & 水深 & 河床高 & 堰(上流) & 堰(下流) & T-P & T-P2乗 \\
\hline 1 & 860.16 & $-5.42(9.77)$ & 71.54(36.07) & $-62.89(29.22)$ & & $0.32(0.13)$ & & $-6.47 \mathrm{E}-03(1.99 \mathrm{E}-03)$ & & \\
\hline 2 & 861.13 & $11.28(4.45)$ & & & & $0.36(0.11)$ & & $-6.53 \mathrm{E}-03(1.99 \mathrm{E}-03)$ & & \\
\hline 3 & 862.14 & $-26.86(23.94)$ & $75.13(36.26)$ & $-65.83(29.38)$ & & $0.24(0.15)$ & & $-6.59 \mathrm{E}-03(1.99 \mathrm{E}-03) 58.5$ & & \\
\hline 4 & 862.15 & $-44.79(21.39)$ & $93.76(34.66)$ & $-77.48(28.71)$ & & & & $-8.34 \mathrm{E}-03(1.99 \mathrm{E}-03) 109$ & & \\
\hline 5 & 862.21 & $6.89(13.27)$ & $71.67(36.26)$ & $-62.82(29.37)$ & & $0.31(0.13)$ & & $-6.46 \mathrm{E}-03(1.99 \mathrm{E}-03)$ & & \\
\hline
\end{tabular}

$156.90(956.89)$

\begin{tabular}{llllllllll} 
選択回数 & 7 & 8 & 1 & 9 & 1 & 10 & 3 & 1 \\
\hline
\end{tabular}
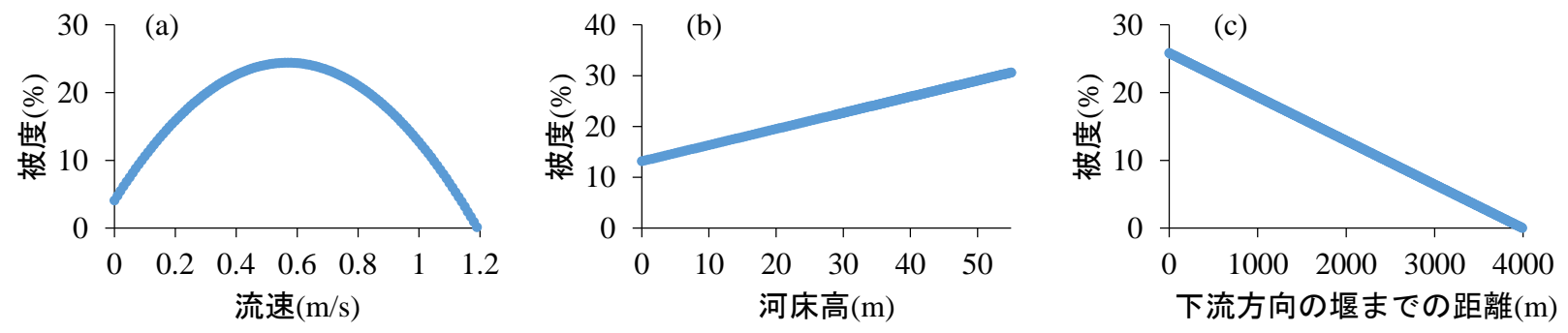

図-8オオカナダモの被度の関係性か強かった变数である (a) 流速, (b) 河床高, (c) 下流方向の堰までの距離の 応答曲線. なお，他の変数は，被度が10\%以上であったユニットの平均值を用いている

本研究では，UAVを用いて，オオカナダモの被度を 定量モニタリングする手法を確立することができ， UAVが河川における外来沈水植物の繁茂状況を定量化 するのに有効であることが示された，さらに，得られた データを用いて，才オカナダモの被度を左右する環境条 件を明らかにすることを試みた結果，オオカナダモの被 度には，下流方向の堰までの距離が最も強く影響を与え ていることが示された。本研究で構築した手法は，今 後, 河川における沈水植物のモニタリングや, 繁茂条件 の解明に大いに役立つツールとなるであろう。

謝辞 : 本研究は国土交通省受託研究「佐波川の河床掘 削・堰撤去が河川環境に与える影響の研究，研究代表 者：赤松良久」の一環として行われた．また，本研究の 一部は，平成27年度河川基金（公益財団法人河川財団） の助成により行われた．本研究に際して，国土交通省中 国地方整備局から貴重なデータの提供を頂いた。ここに 記して謝意を表す。

\section{参考文献}

1) Santos, M. J., Anderson, L. W. and Ustin, S. L.: Effects of invasive species on plant communities: an example using submersed aquatic plants at the regional scale, Biol Invasions, Vol.13, pp.443-457, 2011.

2) 国立環境研究所 侵入生物データベース : https://www.nies.go.jp/biodiversity/invasive/DB/detail/80670_ref.h tml

3) Pimentel, D., Lach, L., Zuniga, R., and Morrison, D.: Environmental and Economic Costs of Nonindigenous Species in the United States, BioScience, Vol.50, pp.53-65, 2000.

4) Haramoto, T., and Ikushima, I.: Life cycle of Egeria densa Planch., an aquatic plant naturalized in Japan, Aquatic Botany, Vol.30, pp.389-403, 1988.

5) 琵琶湖博物館 WEB図鑑「外来生物」: http://www.lbm.go.jp/emuseum/zukan/gairai/data/ookanadamo.ht $\mathrm{ml}$

6) 内田朝子, 白金晶子, 洲崎登子, 硲 伸夫, 水野 修, 椿 隆明 : 矢作川における要注意外来生物オオカナダモ（Egeria densa）の繁茂状況之駆除活動，矢作川研究 No.18, pp.33-40, 2014.

7) Hestir, E. L., Khanna, S., Andrew, M. E., Santos, M. J., Viers, J. H., Greenberg, J. A., Rajapakse, S. S., Ustin, S. L.: Identification of invasive vegetation using hyperspectral remote sensing in the California Delta ecosystem, Remote Sensing of Environment, Vol.112, pp.4034-4047, 2008.

8) 村上拓彦, 望月翔太 : リモートセンシングによる植生マッ ピング，日本生態学会誌 64,pp.233-242, 2014.

9）赤松良久, 上鶴翔梧, 高村紀彰, 神谷大介, 清木隆博, 竹 村柴苑，乾隆帝，鎌田磨人：中国地方における流域の流程 区分図の作成とその活用法の検討，河川技術論文集，第20 巻, pp.169-174, 2014.

(2015. 9. 30受付) 